\title{
Pengaruh Profitabilitas dan Manajemen Laba terhadap Pajak Penghasilan Badan Terutang
}

\author{
Khoirotun Nisa", Khanifah Khanifah dan Atieq Amjadallah Alfie \\ Jurusan Akuntansi, Fakultas Ekonomi, Universitas Wahid Hasyim \\ *Email: khoirotunnisa0309@gmail.com
}

\begin{abstract}
This study aims to examine the effect of profitability which is proxied by gross profit margin, net profit margin and earnings management on corporate income tax payable to manufacturing companies. In this study the gross profit margin measures the efficiency of calculating the cost of goods or production costs. Net profit margin measures net income after tax. And earnings management to find out the company's performance. This study used a sample of 63 manufacturing companies listed on the Indonesia Stock Exchange in 2015-2017. The analysis tool uses descriptive statistical analysis test, classic assumption test and multiple linear regression using the SPSS program. In collecting the data, this study analyzes secondary data obtained from www.idx.co.id during the year of observation and the Indonesia Stock Exchange. The results showed that gross profit margin had a significant and negative effect on outstanding corporate income tax. Net profit margin does not have a significant effect on the income tax payable entity. While the earnings management variable has a significant and positive effect on the corporate income tax payable.
\end{abstract}

Keywords: Outstanding Corporate Income Tax, Gross Profit Margin, Net Profit Margin, Earnings Management.

\begin{abstract}
Abstrak
Penelitian ini bertujuan untuk menguji pengaruh profitabilitas yang diukur dengan margin laba kotor, margin laba bersih dan manajemen laba terhadap hutang pajak penghasilan perusahaan kepada perusahaan manufaktur. Dalam penelitian ini margin laba kotor mengukur efisiensi penghitungan biaya barang atau biaya produksi. Margin laba bersih mengukur laba bersih setelah pajak. Dan manajemen laba untuk mengetahui kinerja perusahaan. Penelitian ini menggunakan sampel 63 perusahaan manufaktur yang terdaftar di Bursa Efek Indonesia pada 2015-2017. Alat analisis menggunakan uji analisis statistik deskriptif, uji asumsi klasik dan regresi linier berganda menggunakan program SPSS. Dalam mengumpulkan data, penelitian ini menganalisis data sekunder yang diperoleh dari www.idx.co.id selama tahun pengamatan dan Bursa Efek Indonesia. Hasil penelitian menunjukkan bahwa marjin laba kotor memiliki pengaruh yang signifikan dan negatif terhadap pajak penghasilan badan. Margin laba bersih tidak memiliki pengaruh yang signifikan terhadap hutang pajak penghasilan badan. Sedangkan variabel manajemen laba berpengaruh signifikan dan positif terhadap hutang pajak penghasilan.
\end{abstract}

Kata kunci: Margin Laba Kotor, Margin Laba Bersih, Manajemen Laba, Pajak Penghasilan

\section{PENDAHULUAN}

Laporan keuangan merupakan bagian yang tidak terpisahkan dari SPT Tahunan PPh. Laporan keuangan dalam penyusunan SPT Tahunan berfungsi sebagai sumber dokumen yang mengarahkan dari laba rugi perusahaan kepada perhitungan pajak terutang. Laba merupakan tolok ukur keberhasilan perusahaan dalam meningkatkan dan mempertahankan usahanya. Pertumbuhan suatu perusahaan tergantung dari kelangsungan bisnis serta profitabilitasnya. Profitabilitas menunjukkan kemampuan perusahaan dalam menghasilkan laba bersih yang merupakan hasil dari sejumlah kebijakan dan keputusan perusahaan. Rasio profitabilitas mengukur seberapa besar kemampuan perusahaan dalam menghasilkan keuntungan, semakin tinggi tingkat profitabilitas maka semakin tinggi kemampuan suatu perusahaan untuk bertahan dalam menjalankan usahanya tersebut. 
Ardyansyah (2013) menyatakan bahwa profitabilitas tidak berpengaruh signifikan terhadap effective tax rate (ETR). Syafri (2008) berpendapat bahwa rasio profitabilitas menggambarkan kemampuan perusahaan menghasilkan laba melalui semua kemampuan dan sumber yang ada. Beberapa indikator yang biasa digunakan untuk mengukur profitabilitas antara lain : Gross Profit Margin dan Net Profit Margin.

Menurut Syamsuddin (2009) berpendapat bahwa Gross Profit Margin merupakan persentase dari laba kotor yang diperoleh dibandingkan dengan penjualan. Semakin besar Gross Profit Margin maka akan semakin baik keadaan operasi perusahaan, karena harga pokok penjualan relatif lebih rendah dibandingkan dengan penjualan, demikian sebaliknya. Menurut Margaretha (2011) Net Profit Margin digunakan untuk mengukur kemampuan perusahaan memperoleh laba setelah pajak dari setiap rupiah penjualan. Semakin tinggi Net Profit Margin menunjukkan kemampuan perusahaan dalam menghasilkan laba cukup besar. Net Profit Margin yang positif menunjukkan bahwa perusahaan tersebut sehat dan tidak mengalami kerugian.

Manajemen laba dilakukan oleh manajer untuk memenuhi tanggung jawab terhadap pemilik perusahaan akan laba yang terus meningkat dan nilai pasar perusahaan yang naik pada jangka waktu tertentu, sehingga mereka dikontrak kembali untuk menjabat sebagai manajer di perusahaan tersebut pada periode berikutnya. Kurangnya informasi dan pengetahuan pemilik perusahaan dan pihak eksternal perusahaan seperti investor, serta terpusatnya perhatian pemilik perusahaan dan investor terhadap laba seringkali mendorong manajer untuk memanipulasi laba. Hal ini dapat mengakibatkan munculnya potensi pelanggaran dan kejahatan yang dibuat oleh pihak manajemen perusahaan. Namun, manajemen laba tidak selalu menjadi upaya negatif yang merugikan karena tidak selamanya manajemen laba berorientasi pada memanipulasi data akuntansi, tetapi lebih condong terhadap pemilihan metode akuntansi yang dipilih oleh pihak manajemen untuk tujuan tertentu dalam batasan GAAP. Elok (2012) manajemen laba berpengaruh negatif terhadap kinerja keuangan perusahaan. Artinya pengaruh yang diakibatkan dari praktik manajemen laba memberikan dampak menurunnya kinerja keuangan perusahaan.

Salah satu tujuan perusahaan baik manufaktur maupun non-manufaktur adalah memaksimalkan kesejahteraan pemegang saham atau investor dengan cara memaksimalkan nilai perusahaan dengan cara memperoleh laba maksimum (Anwar Pohan, 2013). Disisi lain membayar pajak merupakan salah satu kewajiban perusahaan yang tidak dapat terhindarkan. Namun, perusahaan dapat melakukan manajemen pajak agar jumlah pajak yang harus dibayar menjadi rendah. Salah satu manajemen pajak yang berkaitan dengan penggunaan hutang adalah adanya beban bunga atas hutang yang termasuk biaya usaha yang dapat menjadi pengurang penghasilan, sehingga menyebabkan laba kena pajak perusahaan menjadi berkurang yang pada akhirnya akan mengurangi jumlah pajak yang harus dibayar perusahaan.

Berdasarkan adanya penelitian terdahulu menurut Syamsudin dan Primayuta (2009) menyatakan bahwa Net Profit Margin berpengaruh negatif namun juga tidak signifikan terhadap perubahan pajak penghasilan badan. Sedangkan menurut Purwanto dan Chelsea (2016) menyatakan bahwa Net Profit Margin berpengaruh positif terhadap pajak penghasilan badan. Menurut Dewi et al (2009) menyatakan bahwa manajemen laba berpengaruh terhadap kinerja perusahaan. menurut Elok (2012) berpendapat bahwa manajemen laba berpengaruh negatif terhadap kinerja keuangan perusahaan. Menurut Agustina dan Silvia (2012) berpendapat bahwa Gross Profit Margin berpengaruh negatif dan signifikan terhadap perubahan laba. Sedangkan Luluk Muhimatul Ifada dan Tiara Puspitasari (2016) menyatakan bahwa Gross Profit Margin berpengaruh positif terhadap perubahan laba.

Berdasarkan adanya perbedaan yang telah dilakukan oleh para peneliti terdahulu mengenai pajak penghasilan badan terutang, maka dalam penelitian ini digunakan rasio profitabilitas dan manajemen laba untuk membuktikan bagaimana sebenarnya pengaruh rasio profitabilitas terhadap pajak penghasilan adan terutang. maka penulis menganalisis pengaruh profitabilitas dan manajemen laba terhadap pajak penghasilan badan terutang (studi pada perusahaan manufaktur yang terdaftar di bursa efek indonesia tahun 2015-2017). 


\section{METODE PENELITIAN}

Jenis penelitian yang digunakan adalah penelitian deskriptif dengan pendekatan kuantitatif. Variabel yang digunakan adalah variabel bebas (independen) Gross Profit Margin (GPM), Net Profit Margin (NPM) dan Manajemen Laba serta variabel terikat (dependen) meliputi pembiayaan pajak penghasilan badan terutang. Sumber data yang digunakan adalah data sekunder.

Teknik pengambilan sampel menggunakan teknik purposive sampling dengan kriteria sebagai berikut; (1) Perusahaan manufaktur yang terdaftar di Bursa Efek Indonesia secara berturutturut selama periode 2015-2017, (2) Perusahaan manufaktur yang mempublikasikan laporan tahunan secara berturut-turut selama periode 2015-2017, (3) Perusahaan manufaktur yang tidak mengalami kerugian selama periode 2015-2017, (4) Perusahaan manufaktur yang memberikan laporan tahunan dalam satuan mata uang rupiah, (5) Memiliki kelengkapan informasi yang dibutuhkan dalam keperluan penelitian. Sampel yang digunakan sebanyak 63 data meliputi 21 perusahaan manufaktur dalam 3 tahun periode. Teknik analisis data yang digunakan adalah statistik deskriptif, uji asumsi klasik (uji normalitas, multikoliniearitas, heterokedastisitas, uji autokorelasi), analisis regresi linier berganda dan uji hipotesis (uji t) dan uji koefisien determinasi $\mathrm{R}^{2}$.

\section{HASIL DAN PEMBAHASAN}

Penelitian ini menggunakan data Gross Profit Margin (GPM), Net Profit Margin (NPM), Manajemen Laba dan pajak penghasilan badan terutang dari tahun 2015-2017. Data tersebut merupakan data dari perusahaan manufaktur.

\section{Uji Normalitas}

Uji normalitas bertujuan untuk menguji apakah dalam model regresi, variabel terikat dan variabel bebas keduanya memiliki distribusi normal atau tidak. Model regresi yang baik memiliki distribusi yang normal atau mendekati normal. Untuk menguji apakah distribusi data normal atau tidak, yaitu dengan analisis grafik dan uji statistik. Berdasarkan pada penelitian sebelumnya dan beberapa pakar statistik, belum tentu data yang lebih dari 30 sampel bisa dipastikan berdistribusi normal, sebaliknya data yang dengan jumlah kurang dari 30 sampel belum tentu tidak berdistribusi normal, untuk itu perlu suatu pembuktian menggunakan uji normalitas (Ghozali, 2016).

Normalitas data dilihat melalui histogram display normal curve, berdasarkan bentuk gambar kurvanya data dikatakan normal jika bentuk kurva memiliki kemiringan yang cenderung imbang, pada sisi kiri maupun sisi kanan, dan kurva berbentuk lonceng yang hampir sempurna. Dan normalitas juga dapat dilakukan dengan melihat kurva normal p-plot, penyebaran data (titik) pada sumbu diagonal dari grafik.

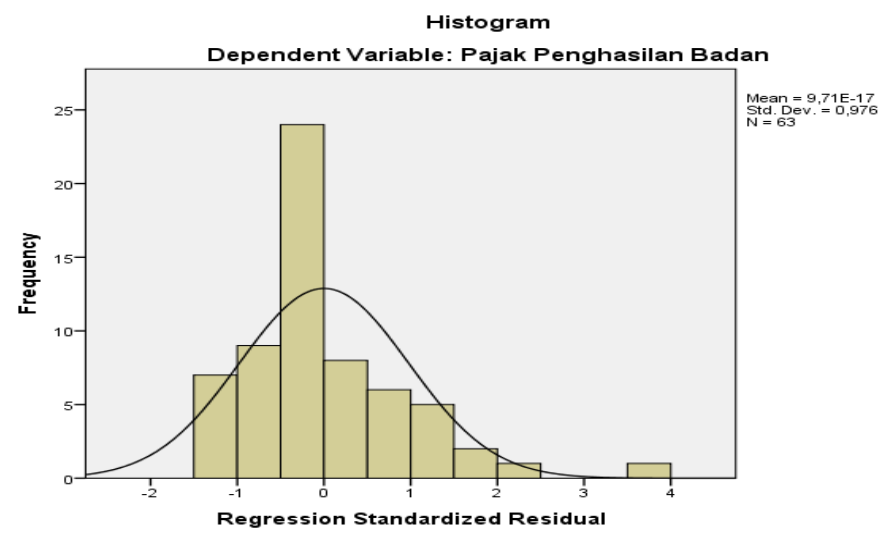

Gambar 1. Grafik Histogram 


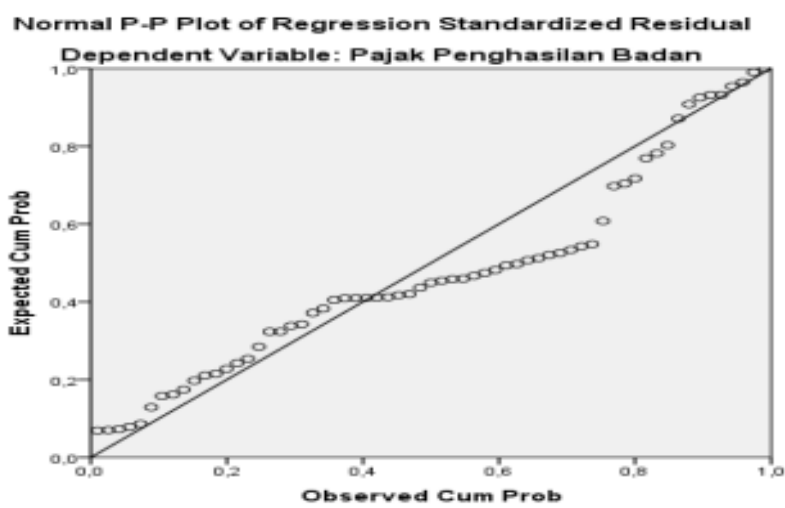

Gambar 2. Grafik Normal Probability Plot

Sumber: data diolah tahun 2019.

\section{Analisis Uji Statistik}

Untuk mendapatkan tingkat uji normalitas yang lebih signifikan maka penelitian ini juga menggunakan uji statistik non parametric Kolmogorov-Smirnov. Data yang berdistribusi normal ditunjukkan dengan nilai signifikansi diatas 0,05 atau 5\% (Ghozali, 2016).

Tabel 2. Hasil Uji Normalitas Secara Statistik One-Sample Kolmogorov-Smirnov Test

\begin{tabular}{|ll|l|}
\hline & & $\begin{array}{l}\text { Unstandardized } \\
\text { Residual }\end{array}$ \\
\hline N & & 63 \\
Normal Parameters ${ }^{\mathrm{a}, \mathrm{b}}$ & Mean &, 0000179 \\
& Std. Deviation & 1,68096 \\
Most Extreme Differences & Absolute &, 197 \\
& Positive &, 197 \\
& Negative &,- 065 \\
Test Statistic & &, 197 \\
Asymp. Sig. (2-tailed) & &, 061 \\
\hline
\end{tabular}

a. Test distribution is Normal.

b. Calculated from data.

c. Lilliefors Significance Correction.

(Sumber : output SPSS yang telah diolah, 2019)

Dapat disimpulkan bahwa pengujian normalitas mengunakan uji kolmogorov-smirnov dapat di ketahui bahwa nilai Unstandardized Residual memiliki Asymp sig > 0.05, ini mengartikan bahwa semua data terdistribusi normal akan tetapi nilai sig. lebih dari 0.05 maka dinyatakan signifikan.

\section{Uji Multikolinearitas}

Uji multikolinieritas bertujuan untuk menguji apakah model regresi yang ditemukan adanya korelasi antar variabel bebas (independen). Apabila terjadi korelasi antar variabel bebas, maka terdapat masalah multikolinieritas pada model regresi tersebut. Untuk mengetahui terjadi atau tidaknya multikolinieritas dengan melihat nilai tolerance value dan variance inflation factor (VIF). Hasil perhitungan data diperoleh nilai tolerance dan VIF sebagai berikut: 
Tabel 3. Hasil Uji Multikolonieritas

\begin{tabular}{|c|r|r|}
\hline \multirow{2}{*}{ Model } & \multicolumn{2}{|c|}{$\begin{array}{c}\text { Collinearity } \\
\text { Statistics }\end{array}$} \\
\cline { 2 - 3 } (Constant) & Tolerance & \multicolumn{1}{c|}{ VIF } \\
\hline GPM &, 709 & 1,410 \\
NPM &, 705 & 1,419 \\
Manajemen &, 983 & 1,017 \\
Laba & & \\
\hline
\end{tabular}

(Sumber : output SPSS yang telah diolah, 2019)

Dari hasil perhitungan nilai tolerance menunjukkan variabel independen memiliki nilai tolerance lebih dari 0,10 yang berarti tidak ada korelasi antar variabel independen. Hasil perhitungan nilai VIF untuk variabel GPM, NPM dan Manajemen Laba kurang dari 10. Jadi dapat disimpulkan tidak ada multikolonieritas antar variabel independen dalam regeresi.

\section{Uji Heterokedastisitas}

Uji heteroskedastisitas untuk menguji apakah dalam model regresi terjadi ketidaksamaan varians dan residual atau pengamatan ke pengamatan lain. Jika varians dari residual satu pengamatan ke pengamatan yang lain tetap, maka disebut heteroskedastisitas. Untuk menentukan heteroskedastisitas dapat menggunakan grafik scatterplot. Adapun grafik scatterplot sebagai berikut ini:

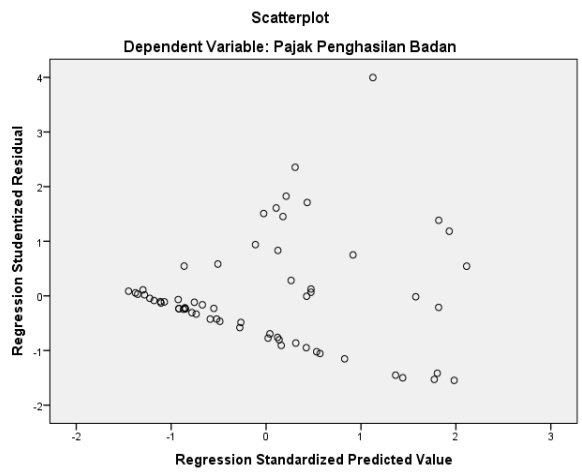

Gambar 4. Grafik Scatterplot

(Sumber : output SPSS yang diolah, 2019)

Dari grafik scatterplot terlihat bahwa titik-titik menyebar secara acak serta tersebar baik diatas maupun dibawah angka 0 pada sumbu Y. dengan demikian dapat disimpulkan bahwa model regresi ini tidak terjadi heteroskedastisitas.

\section{Uji Regresi Linear Berganda}

Model regresi berganda bertujuan untuk memprediksi besar variabel dependen dengan menggunakan data variabel dependen yang sudah diketahui besarnya. Model regresi linier berganda umumnya digunakan untuk menguji pengaruh dua atau lebih variabel independen terhadap variabel dependen dengan skala pengukuran interval atau rasio dalam suatu persamaan linier. 
Tabel 6. Hasil Analisis Linear Berganda Coefficients $^{\mathbf{a}}$

\begin{tabular}{|c|c|c|c|}
\hline \multirow[b]{2}{*}{ Model } & \multicolumn{2}{|c|}{$\begin{array}{c}\text { Unstandardized } \\
\text { Coefficients }\end{array}$} & \multirow{2}{*}{$\begin{array}{c}\begin{array}{c}\text { Standardized } \\
\text { Coefficients }\end{array} \\
\text { Beta }\end{array}$} \\
\hline & B & $\begin{array}{l}\text { Std. } \\
\text { Error }\end{array}$ & \\
\hline $1 \quad$ (Constant) & 4,545 & 4,889 & \\
\hline GPM & $-2,981$ & 1,879 &,- 214 \\
\hline NPM & 2,254 & 5,375 & ,568 \\
\hline $\begin{array}{l}\text { Manajemen } \\
\text { Laba }\end{array}$ & 5,262 & 8,693 & ,069 \\
\hline
\end{tabular}

(Sumber : output SPSS yang telah diolah, 2019)

Berdasarkan hasil olah data dengan menggunakan regresi berganda pada tabel 6, maka dapat diketahui bahwa besarnya pengaruh masing-masing variabel yang digunakan dalam penelitian X1 $(\mathrm{GPM})=-2,981, \mathrm{X} 2(\mathrm{NPM})=2,254$ dan X3 $(\mathrm{ML})=5,262$ dengan konstanta sebesar 4,545, sehingga model persamaan regresi yang diperoleh adalah :

$$
\mathrm{Y}=4,545-2,981 \mathrm{X} 1+2,254 \mathrm{X} 2+5,262 \mathrm{X} 3+\mathrm{e}
$$

\section{Uji Pengaruh Parsial (Uji T)}

Uji ini digunakan untuk menguji pengaruh variabel independen terhadap variabel dependen secara parsial. Menurut pendapat Ghozali (2005) menyatakan bahwa uji statistik t pada dasarnya untuk menunjukan seberapa jauh pengaruh satu variabel independen secara individual dalam menerangkan variabel dependen. Uji ini dapat dilakukan dengan membandingkan $\mathrm{t}$ hitung dengan $\mathrm{t}$ tabel. Maka t tabel dalam penelitian ini adalah 2,00100. Adapun kriteria pengambil keputusan yang digunakan dalam penelitian ini adalah sebagai berikut:

1. Jika nilai signifikan $>0,05$ maka hipotesis ditolak. Ini berari secara parsial variabel independen tidak mempunyai pengaruh secara signifikan terhadap variabel depeden.

2. Jika nilai signifikan $\leq 0,05$ maka hipotesis diterima. Ini berarti secara parsial variabel independen tersebut mempunyai pengaruh yang signifikan terhadap variabel dependen.

Tabel 7. Hasil Uji T

Coefficients $^{\mathrm{a}}$

\begin{tabular}{|l|r|r|r|r|r|}
\hline \multirow{2}{*}{ Model } & \multicolumn{2}{|c|}{$\begin{array}{c}\text { Unstandardized } \\
\text { Coefficients }\end{array}$} & \multicolumn{2}{c|}{$\begin{array}{c}\text { Standardized } \\
\text { Coefficients }\end{array}$} & \multirow{2}{*}{} \\
\cline { 2 - 4 } & \multicolumn{1}{|c|}{ B } & Std. Error & Beta & \multicolumn{1}{c|}{ S } & \multicolumn{1}{c|}{ Sig. } \\
\hline (Constant) & 4,545 & 4,889 & &, 930 &, 356 \\
GPM & $-2,981$ & 1,878 &,- 214 & $-1,586$ &, 118 \\
NPM & 2,254 & 5,375 &, 568 & 4,193 &, 000 \\
Manajemen Laba & 5,262 & 8,693 &, 069 &, 605 &, 547 \\
\hline
\end{tabular}

a. Dependent Variable: Pajak Penghasilan Badan

(Sumber : output SPSS yang diolah, 2019)

Pengujian hipotesis secara parsial yang dilakukan dalam penelitian ini untuk mengetahui pengaruh dari masing-masing variabel independen terhadap variabel dependen adalah:

1. Pengaruh Gross Profit Margin Terhadap Pajak Penghasilan Badan Terutang (H1)

Bahwa diperoleh nilai signifikansi variabel Gross Profit Margin sebesar 0,118 > 0,05 (taraf signifikansi). Selain itu juga dapat dilihat dari hasil perbandingan antara t-hitung dan t-tabel yang 
menunjukkan nilai t-hitung sebesar -1,586, sedangkan t-tabel 2,00100. Hal ini nilai thitung < ttabel $(-1,586<2,00100)$ sehingga Ho diterima.

2. Pengaruh Net Profit Margin Terhadap Pajak Penghasilan Badan Terutang (H2)

Bahwa diperoleh nilai signifikansi variabel Net Profit Margin sebesar 0,000 $<0,05$ (taraf signifikansi). Selain itu juga dapat dilihat dari hasil perbandingan antara t-hitung dan t-tabel yang menunjukkan nilai t-hitung sebesar 4,193, sedangkan t-tabel 2,00100. Hal ini nilai thitung > ttabel $(4,193>2,00100)$ sehingga Ho ditolak.

3. Pengaruh Manajemen Laba Terhadap Pajak Penghasilan Badan Terutang (H3)

Bahwa diperoleh nilai signifikansi variabel Manajemen Laba sebesar 0,547>0,05 (taraf signifikansi). Selain itu juga dapat dilihat dari hasil perbandingan antara t-hitung dan t-tabel yang menunjukkan nilai t-hitung sebesar 0,605, sedangkan t-tabel 2,00100. Hal ini nilai thitung < ttabel $(0,605<2,00100)$ sehingga Ho diterima.

\section{Uji Koefisien Determinasi $\left(\mathbf{R}^{2}\right)$}

Koefisien determinasi (R2) bertujuan untuk mengetahui seberapa besar kemampuan variabel independen menjelaskan variabel dependen. Dalam output SPSS, koefisien determinasi terletak pada Model Summary ${ }^{b}$ dengan melihat Adjusted $R$ Square, karena disesuaikan dengan jumlah variabel independen yang digunakan dalam penelitian.

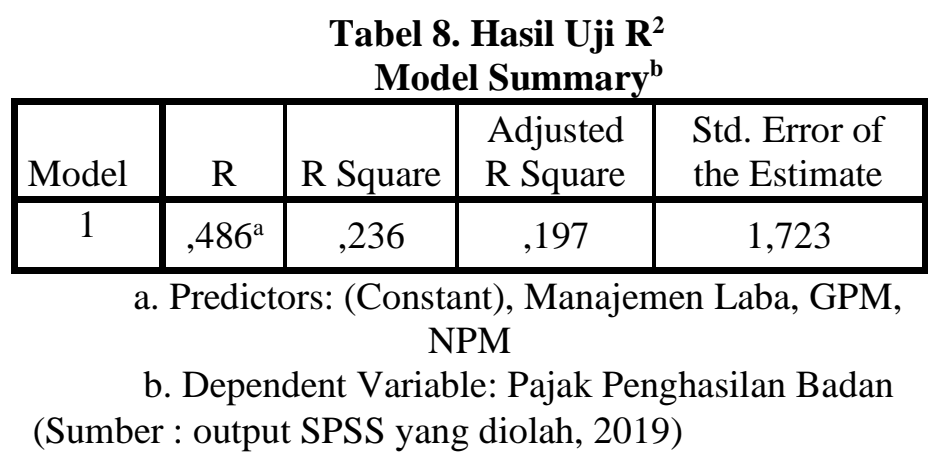

\section{KESIMPULAN}

Berdasarkan hasil uji t (parsial) pada model regresi, menunjukkan bahwa Gross Profit Margin memiliki arah koefisien regresi negatif sebesar $-1,586$ dan nilai signifikansi yang dihasilkan lebih besar dari tingkat signifikansi sebesar 0,118 $>0,05$. Berdasarkan hal tersebut dapat disimpulkan bahwa Ha1 diterima, secara parsial variabel Gross Profit Margin berpengaruh signifikan dengan arah koefisien negatif terhadap variabel Pajak Penghasilan Badan Terutang.

Berdasarkan hasil uji t (parsial) pada model regresi, menunjukkan bahwa Net Profit Margin memiliki arah koefisien regresi positif sebesar 4,193 dan nilai signifikansi yang dihasilkan lebih kecil dari tingkat signifikansi sebesar $0,000<0,05$. Berdasarkan hal tersebut dapat disimpulkan bahwa Ha2 ditolak, secara parsial variabel Net Profit Margin tidak berpengaruh signifikan dengan arah koefisien positif terhadap variabel Pajak Penghasilan Badan Terutang.

Berdasarkan hasil uji t (parsial) pada model regresi, menunjukkan bahwa Manajemen Laba memiliki arah koefisien regresi positif sebesar 0,605 dan nilai signifikansi yang dihasilkan lebih besar dari tingkat signifikansi sebesar 0,547 >0,05. Berdasarkan hal tersebut dapat disimpulkan bahwa Ha3 diterima, secara parsial variabel Manajemen Laba berpengaruh signifikan dengan arah koefisien positif terhadap variabel Pajak Penghasilan Badan Terutang.

Penulis menyadari bahwa masih banyak ada kekurangan dalam penelitian ini. Jadi untuk penelitian selanjutnya semoga dapat menjadi bahan pertimbangan dan dapat memperbaiki dalam hal jumlah variabel dan kriteria sampel, pemilihan rasio keuangan, model pendeteksian lain yang lebih akurat dalam memprediksi manajemen laba sehingga dapat menemukan faktor-faktor yang tepat dalam mempengaruhi pajak peghasilan badan terutang.

\section{DAFTAR PUSTAKA}

Ardyansyah, Muhammad. (2013). Pengaruh Corporate Governance, Leverage dan Profitabilitas Terhadap Manajemen Laba. Jurnal Akuntansi, Universitas Maritim Raja Ali Haji. 
Agustina dan Silvia. (2012). Analisis Pengaruh Kinerja Keuangan dalam Memprediksi Pertumbuhan Laba. Jurnal Aplikasi Manajemen, Volume 10, Nomor 3, 669-681.

Erly Suandy, 2011 Edisi 5. Perencanaan Pajak. Jakarta : Penerbit Salemba Empat.

Elok Dwi Mulyono. (2012). Skripsi. "Pengaruh Manajemen Laba (Earning Management) Terhadap Kinerja Keuangan". Universitas Islam Negeri.

Faozi, K. 2002. Analisis Hubungan Trade off antara Manajemen Laba Akrual dengan Manajemen Laba Riil di Indonesia Periode 2007-2010. Skripsi Fakultas Ekonomi Universitas Indonesia.

Ghozali, Imam. (2016). Aplikasi analisis multivariate dengan program IBM SPSS 23 cetakan kedelapan. Semarang : Badan Penerbit Universitas Diponegoro.

Hadri Kusuma. 2006. Dampak Manajemen Laba terhadap Relevansi Informasi Akuntansi : Bukti Empiris dari Indonesia. Jurnal Akuntansi dan Keuangan, VOL. 8, NO. 1, MEI 2006 : 1-12.

Ifada, Luluk Muhimatul. Dan Puspitasari, Tiara. (2016). Analisis pengaruh rasio keuangan terhadap perubahan laba. Jurnal akuntansi \& auditing, volume 13, No. 1, 97-108.

Kasmir. 2008. Bank dan Lembaga Keuangan Lainnya. Edisi Revisi 2008. Jakarta.

Margaretha, Farah., da Asmariani, Andhini. (2011). Faktor-Faktor Agency Theory yang Mempengaruhi Hutang. Media Riset bisnis dan Manajemen.

Purwanto dan Bina. (2016). Analysis of Financial Ratio towards Earning Growth in Mining Companies. Universal Journal of Industrial and Business Management, 81-87.

Priyatno, Duwi. (2014). Mandiri belajar analisis data dengan SPSS. Yogyakarta : Media Kom.

Peraturan Perpajakan Terbaru s/d Maret 2017.

Pohan, Chairil Anwar. 2013. Manajemen Perpajakan. Gramedia Pustaka Utama. Jakarta.

Syamsudin dan Primayuta, Ceky. (2009). Rasio keuangan dan prediksi perubahan laba perusahaan manufaktur yang terdaftar di bursa efek indonesia. BENEFIT jurnal manajemen dan bisnis, volume 13, nomor 1, 61-69.

Siti Resmi. 2008. Perpajakan Teori dan Kasus. Edisi 4. Jakarta : Salemba Empat.

Septiani, Mutria Lisa. (2009). Analisis Pengaruh Modal Sendiri dan Hutang Jangka Panjang Terhadap PPh Badan Terutang (Studi Kasus Pada Perusahaan Industri Kimia Yang Terdaftar di Bursa Efek Indonesia Tahun 2003-2007. Skripsi, Jakarta : Universitas Islam Syarif Hidayatullah.

Suwardjono. 2013. Teori Akuntansi Perekayasaan Pelaporan Keuangan. Yogyakarta : BPFEYogyakarta.

Wildani, Anastasia Rizka. (2012). Pengaruh Perubahan Tarif Pajak Penghasilan Wajib Pajak Badan dan Karakteristik Perusahaan Terhadap Struktur Modal pada Perusahaan Listing di BEI Periode 2006-2010.

Yuliana, Chandra. 2011. Pengaruh Leverage, Pergantian CEO dan Motivasi Pajak terhadap Manajemen Laba. Jurnal Riset Akuntansi dan Keuangan.

https://sbm.binus.ac.id/2015/11/20/uji-asumsi-klasik-uji-autokorelasi. (diunduh pada tanggal 20 Agustus 2019).

www.idx.co.id (Diunduh pada tanggal 13 Januari 2019)

www.bps.go.id (Diunduh pada tanggal 7 April 2019) 